Jpn. J. Oral Biol., $42: 40-48,2000$.

\title{
ORIGINAL
}

\section{Opened and Closed States of Tight Junctions by Secretory Stimuli in Rat Submandibular Acini}

\author{
Yuichi Sakaguchi, Noriyasu Takai and Yo Yoshida \\ Department of Physiology, Osaka Dental University \\ (Chief : Prof. Yo Yoshida) \\ 8-1, Kuzuhahanazono-cho, Hirakata-shi, Osaka 573-1121, Japan \\ (Received on July 26, 1999 ; Accepted on November 25, 1999)
}

Key words : submandibular gland/tight junction/secretion/microperoxidase

\begin{abstract}
It is widely accepted that the salivary glands secrete primary saliva by osmosis at the acini, and that some of the salivary fluid flows through the tight junctions (paracellular secretory pathway). The aim of this study was to examine the changes in permeability of the acinar tight junction in rat submandibular glands in vivo by electrical stimulation of parasympathetic and sympathetic secretory nerves. The permeability changes of the tight junctions after the stimulation were also examined. The permeability of the tight junction from the interstitium to the lumen was examined by close-arterial infusion with a small ultrastructural tracer, microperoxidase $(\mathrm{MW}=1,630 \mathrm{Da})$, and this tracer was observed by electron microscopy. In the resting gland, the tracer was observed in the interstitial and intercellular spaces, but not within the lumen (closed tight junction). Intraductal injection of hypertonic sucrose $(570-998 \mathrm{mOsm})$ caused a subsequent elevation of the luminal pressure, indicating that osmotic fluid had passed into the lumen. However, the tight junction in the gland remained in the closed state. In the chorda stimulated gland and the stimulated gland of the superior cervical ganglion (stimulated for $2 \mathrm{~min}$ ), the tracer entered the lumen through all the tight junctions, that is, they became permeable to the tracer (the tight junction switched to an opened state). However, the opened tight junction reverted to the closed state after $15-30 \mathrm{~min}$. These findings suggest that submandibular acinar tight junctions switch rapidly to an opened state by nerve stimulation and close again within 15-30 min after the stimulation, and that the paracellular secretory pathway may be involved in the salivary fluid secretion from the acini.
\end{abstract}

抄録：唾液腺の腺房部細胞で生成される原唾夜の水はポンプやチャンネルによって作られた浸透圧によって基 底側間質から腺腔に流れ込むことによって供給されるが，その際の分泌経路は腺房部細胞内を通るルート（経細 胞分泌経路）と細胞間隙を通るルート（傍細胞分泌経路）の 2 つが想定されている。本研究は，傍細胞分泌経路 における tight junction（TJ）の基底側間質から腺腔への物質透過バリヤーとしての機能について，ラット顎下 腺を用いて検討した。TJ のバリヤー機能は microperoxidase $(50 \mu l / \mathrm{min}$ で顔面動脈の䫛下腺枝から投与) をト レーサーとして用いて電顥的に調べた。安静時では, TJ はトレーサーの基底側間質から腺腔への透過を阻止して おり, 腺腔にはトレーサーはみられなかった。また, 安静時の腺腔に高張ショ糖液を導管内から逆行性に注入す ると, 腺腔への水の流入を生じたが,この際にもやはり TJは, トレーサーの腺腔への透過を阻止していた。鼓索 神経または上頸神経節のいずれの電気刺激 (2 分間)でも, トレーサーは細胞間隙から TJを越えて腺腔にみられ るようになった。すなわち, 副交感性および交感性分泌刺激によって，TJはトレーサーを透過させるようになっ た。さらに, 刺激停止 15 分後の TJ も透過性を示していたが, 30 分後の TJ は安静時と同様に非透過性であった。 以上の実験結果から, 靧下腺腺房部細胞の TJは, 安静時には閉じているが, 副交感性および交感性分泌刺激に よってこれが速やかに開いて傍細胞分必経路が通じるようになることが明らかとなった。そして, 分泌刺激によっ て開いた TJは，刺激停止後にすぐには閉じるわけではなく，再び閉じるのは 15一30 分後であった。 


\section{Introduction}

In all secretory epithelia, including the salivary gland, fluid transport is thought to be driven osmotically in response to the transepithelial gradient of electrolytes, principally $\mathrm{Na}^{+}$and $\mathrm{Cl}^{-}$. This gradient is generated by the active transport system localized in the luminal or basolateral membranes of the epithelial cells. In the salivary gland, it is now accepted that primary salivary fluid is osmotically drawn into the acinar lumen through the basolateral and luminal membranes (transcellular secretory pathway) or through the intercellular junctional complexes (paracellular secretory pathway), or a combination of the two routes ${ }^{1,2}$. In the paracellular secretory pathway, the tight junction (zonula occludens) is the sole barrier function between the basolateral and luminal compartments, and selectively controls the passive diffusion of electrolytes and small water-soluble solutes. There is considerable evidence in different epithelial tissues that the tight junction, once regarded as rather static, is a dynamic structure that readily adapts to a variety of developmental, physiological and pathological conditions ${ }^{3,4}$. Although our previous study showed that electrical stimulation of the chorda (parasympathetic stimulation) caused an increase in the permeability of the acinar tight junctions of the rat submandibular gland ${ }^{5}$, there is no information on the states of tight junctions after the stimulation.

As there is no direct method of determining the fluid flow through the tight junction in salivary acini in vivo, we used an indirect approach employing an ultrastructural tracer to histochemically clarify the route and the states of the tight junction by electron microscopy. Horseradish peroxidase has been used as a tracer in this type of experiment in salivary glands $^{5-7)}$, but more recently, this enzyme has been found to have a toxic effect on the cell membrane and tight junction ${ }^{8}$. Microperoxidase is considered to be a more suitable tracer than horseradish peroxidase, as it is very small $(1,630 \mathrm{Da})$ and does not exhibit any toxic effects ${ }^{9,10}$. Additionally, the molecular size of this tracer is small enough $(0.2 \mathrm{~nm})^{11)}$ to pass through the secretory water pathway in the acini. Studies to determine solvent drag have shown that an effective pore radius for the water pathway is $0.4-0.45$ $\mathrm{nm}^{12,13)}$. These studies suggest that the passage for microperoxidase in the salivary gland is via a water transport pathway. Therefore, we tested the permeability of the tight junction for water and small molecules from the interstitium to the lumen using microperoxidase as a tracer. In the present study, we assessed the effect of parasympathetic or sympathetic stimulation on the permeability of the acinar tight junctions, and the states of tight junctions after the stimulation.

\section{Materials and Methods}

\section{Measurements of luminal pressure and stimulation of the gland}

Male Wistar rats $(200-250 \mathrm{~g})$ were fasted for 12 hrs before the experiments, but were given free access to water, and were subsequently anesthetized with an intraperitoneal injection of sodium pentobarbital (50 $\mathrm{mg} / \mathrm{kg}$ ). Additional doses of the anesthetic were given through a femoral venous cannula when required. A tracheal cannula was inserted, and the body temperature was maintained at $37^{\circ} \mathrm{C}$ with the aid of a heating pad.

A $30-\mathrm{mm}$ length of polyethylene tubing (I. D. $=0.28$ $\mathrm{mm}$, O. D. $=0.61 \mathrm{~mm}$ : Intramedic PE-10, Becton \& Dickinson, USA) was inserted into the oral opening of the submandibular duct and fixed in place with an adhesive.

For the secretory stimulation of parasympathetic and sympathetic nerves, the chorda on the main submandibular duct, and the superior cervical ganglion were electrically stimulated continuously for $2 \mathrm{~min}$ with $3.0-5.0 \mathrm{~V}$ pulses at $20 \mathrm{~Hz}$ of $5.0 \mathrm{~ms}$ duration using a bipolar electrode. The luminal pressure was measured 2 min after the stimulation by a pressure transducer connected to the tubing.

In order to produce an osmotic driving force for water influx to the acinar lumen, the glands were retrogradely injected with $30 \mu l$ of 570,713 and 998 mOsm sucrose solution as uniformly as possible using a microsyringe attached between the tubing, with a pressure transducer connected between the syringe 


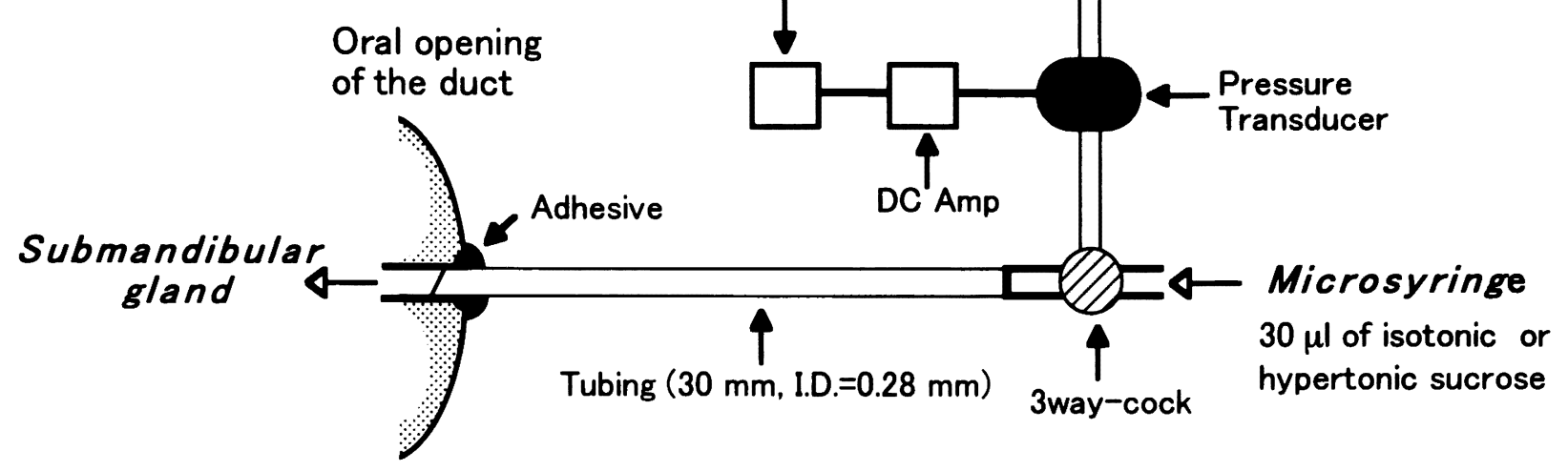

Fig. 1 Diagram of equipment used to measure the luminal pressure in the submandibular gland.

Three way-cocks are for removal of air bubbles, pressure adjustment to zero, and calibration.

and the tubing (Fig. 1). The control gland was injected with $285 \mathrm{mOsm}$ of isotonic sucrose. The luminal pressure was measured $2 \mathrm{~min}$ after the intraductal injection. Previously, we reported that an intraductal injection of $30 \mu l$ of $0.9 \%$ saline caused no functional or histological damage to the rat submandibular gland ${ }^{14)}$, and that $30 \mu l$ of solution can easily reach the acinar lumen ${ }^{15)}$.

The data were presented as means $\pm \mathrm{SE}$, and Student's t-test was used for statistical analysis : a $p$ value less than 0.05 was considered significant.

\section{Histochemical detection of microperox- idase}

Three or 5 heparinized $(500 \mathrm{IU} / \mathrm{kg}$ ) rats were used in each series. The rats were anesthetized with an intraperitoneal injection of sodium pentobarbital ( 50 $\mathrm{mg} / \mathrm{kg}$ ), and the facial artery was retrogradely cannulated with the cannula tip positioned within $1 \mathrm{~mm}$ of the glandular branch junction. Microperoxidase (MP9. Sigma, USA) was dissolved in $0.1 \mathrm{M}$ phosphatebuffered saline ( $\mathrm{pH}$ 7.4) at a concentration of 100 $\mathrm{mg} / \mathrm{ml}$ ), and infused through the arterial cannula using a syringe pump (Harvard, USA) at $50 \mu \mathrm{l} / \mathrm{min}$ for $2 \mathrm{~min}$, as described by Takai et al. ${ }^{16)}$ In the nerve stimulated or the gland undergoing intraductal injection, the tracer infusion was simultaneous with the stimulation or intraductal injection. In some cases, the tracer was infused 15 or $30 \mathrm{~min}$ after the stimulation.
The rat was then perfused through the aorta with icecold normal saline containing heparin $(0.5 \mathrm{IU} / \mathrm{ml})$, followed by $500 \mathrm{ml}$ of ice-cold fixative containing $2.0 \%$ glutaraldehyde in $0.1 \mathrm{M}$ phosphate buffer $(\mathrm{pH} 7.4)$. The glands were then dissected and postfixed in the same fixative for $12-24 \mathrm{hrs}$ at $4^{\circ} \mathrm{C}$. For the demonstration of microperoxidase, the tissues were sliced into $75 \mu \mathrm{m}$ sections on a cryostat and incubated in a modified medium used by Simionescu et al. ${ }^{17}$ ) containing 3,3'-diaminobenzidine tetrahydrochrolyde (12.5 mg), imidazole $(0.1 \mathrm{M})$, and $\mathrm{H}_{2} \mathrm{O}_{2}(0.5 \%, 0.1$ $\mathrm{m} l)$ in $25 \mathrm{~m} l$ of $0.1 \mathrm{M}$ tris buffer $(\mathrm{pH} 8.6)$ at room temperature for $20-30 \mathrm{~min}$. After dehydration through a graded ethanol series, the sections were embedded in Quetol 635/ERL 4206 resin (Taab Lab, England), and then examined with a transmission electron microscope.

\section{Results}

\section{Luminal pressure}

In the resting gland, no spontaneous increase in intraductal pressure was found. Electrical stimulation of the chorda and superior cervical ganglion increased the luminal pressure to $85.6 \pm 13.2$ and $52.5 \pm 20.4$ $\mathrm{mmHg}$, respectively (Fig. 2).

Although the intraductal injection of isotonic sucrose caused slight (less than $5 \mathrm{mmHg}$ ) or no subsequent rise in intraductal pressure, injection of the 


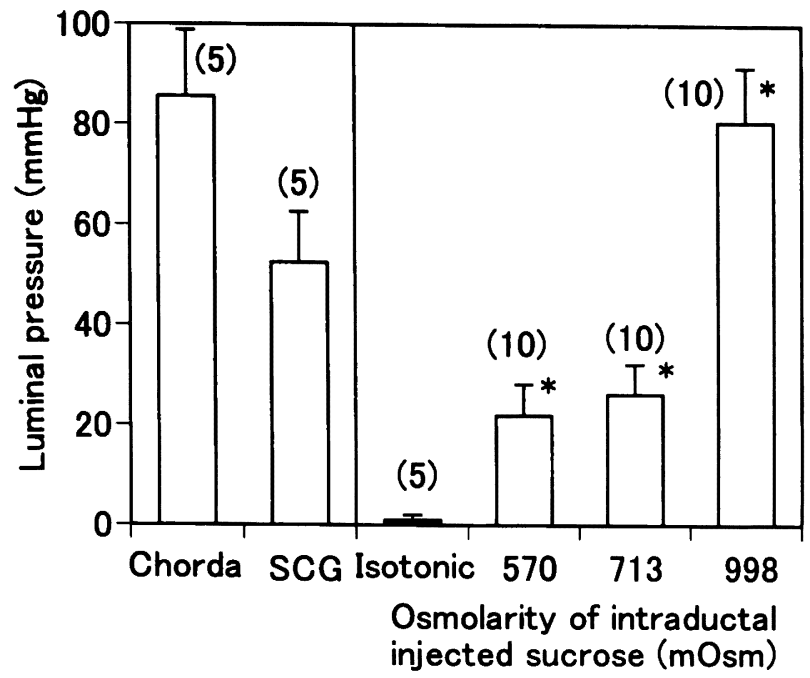

Fig. 2 Luminal pressure changes caused by parasympathetic or sympathetic stimulation, and by intraductal injection of isotonic or hypertonic sucrose.

* Significantly different $(p<0.05)$ from control (injection of isotonic sucrose). The data are presented as Mean + $\mathrm{SE}$. The numbers in parentheses are numbers of samples. Chorda : Electrical stimulation of chorda

SCG : Electrical stimulation of superior cervical ganglion hypertonic sucrose solution caused a sustained elevation of pressure in an osmolarity-dependent manner (Fig. 2). The typical pattern of pressure change under each condition is shown in Figure 3.

\section{Tracer localization}

When the microperoxidase was administered through the glandular artery to the intact resting gland, the reaction products of the tracer were consistently observed in the interstitial and intercellular spaces, but not seen within the lumen in the tight junction region (Fig. 4-A). This indicated that the tight junction is impermeable to microperoxidase, and thus, in the resting gland, is closed to the tracer. Additionally, tight junctions of the resting gland, which was injected intraductally with hypertonic sucrose (998 mOsm), were closed (Fig. 4-B).

In the stimulated gland of the chorda, the reaction products were present in most of the intercellular spaces in acinar cells, including the lumen (Fig. 4-C). A similar distribution of the reaction product was seen when the superior cervical ganglion was stimulat-
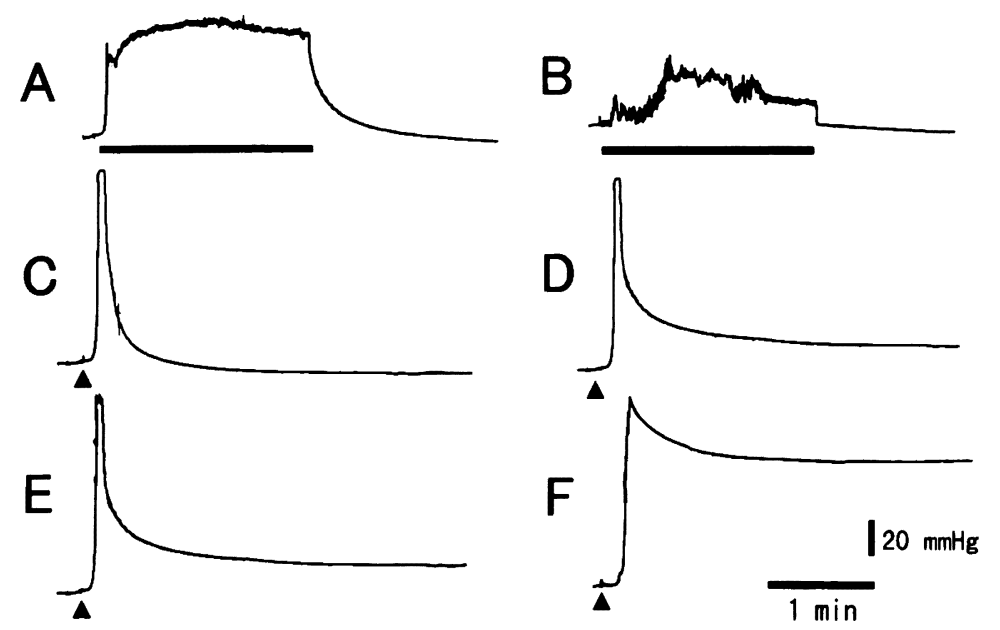

Fig. 3 The typical pattern of luminal pressure changes caused by parasympathetic or sympathetic stimulation, and by intraductal injection of isotonic or hypertonic sucrose.

A. Electrical stimulation of chorda, B. Electrical stimulation of superior cervical ganglion, C. Intraductal injection of isotonic sucrose, D. Intraductal injection of 570 mOsm sucrose, E. Intraductal injection of $713 \mathrm{mOsm}$ sucrose, F. Intraductal injection of 998 mOsm sucrose.

Initial steep rise in pressure in $(\mathrm{C}-\mathrm{F})$ was produced artificially by intraductal injection of solutions.

Horizontal bar : electrical stimulation for chorda in A or superior cervical ganglion in B.

$\Delta$ : Injection. 


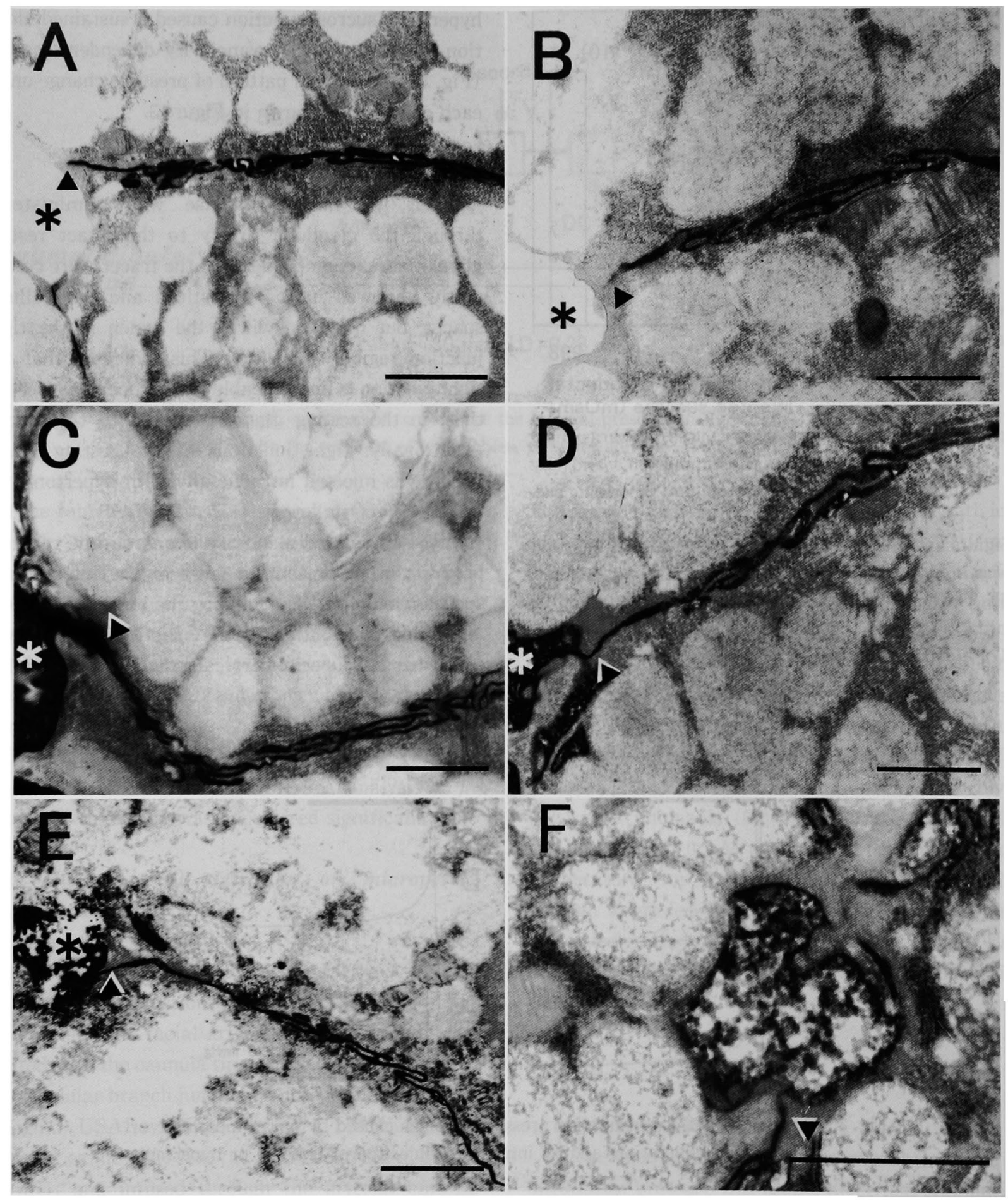

Fig. 4 Electron micrographs of adjacent acinar cells in the submandibular gland infused with microperoxidase. In the resting gland (A), the reaction product of the tracer is seen in the space between acinar cells, but not within the lumen $(*)$ in the tight junction region $(\mathbf{\Delta})$. Similar localization of the reaction product was observed in a gland intraductally injected with hypertonic sucrose (B). In the gland stimulated for 2 min by chorda (C) or by superior cervical ganglion (D), the reaction product is seen in the space between acinar cells, extending all the way into the lumen. In the gland $15 \mathrm{~min}$ after the stimulation of chorda $(E)$, or superior cervical ganglion $(F)$ similar localization of the reaction product was observed $(\operatorname{Bar}=1 \mu \mathrm{m})$. 
Table 1 The states of the acinar tight junctions demonstrated by microperoxidase

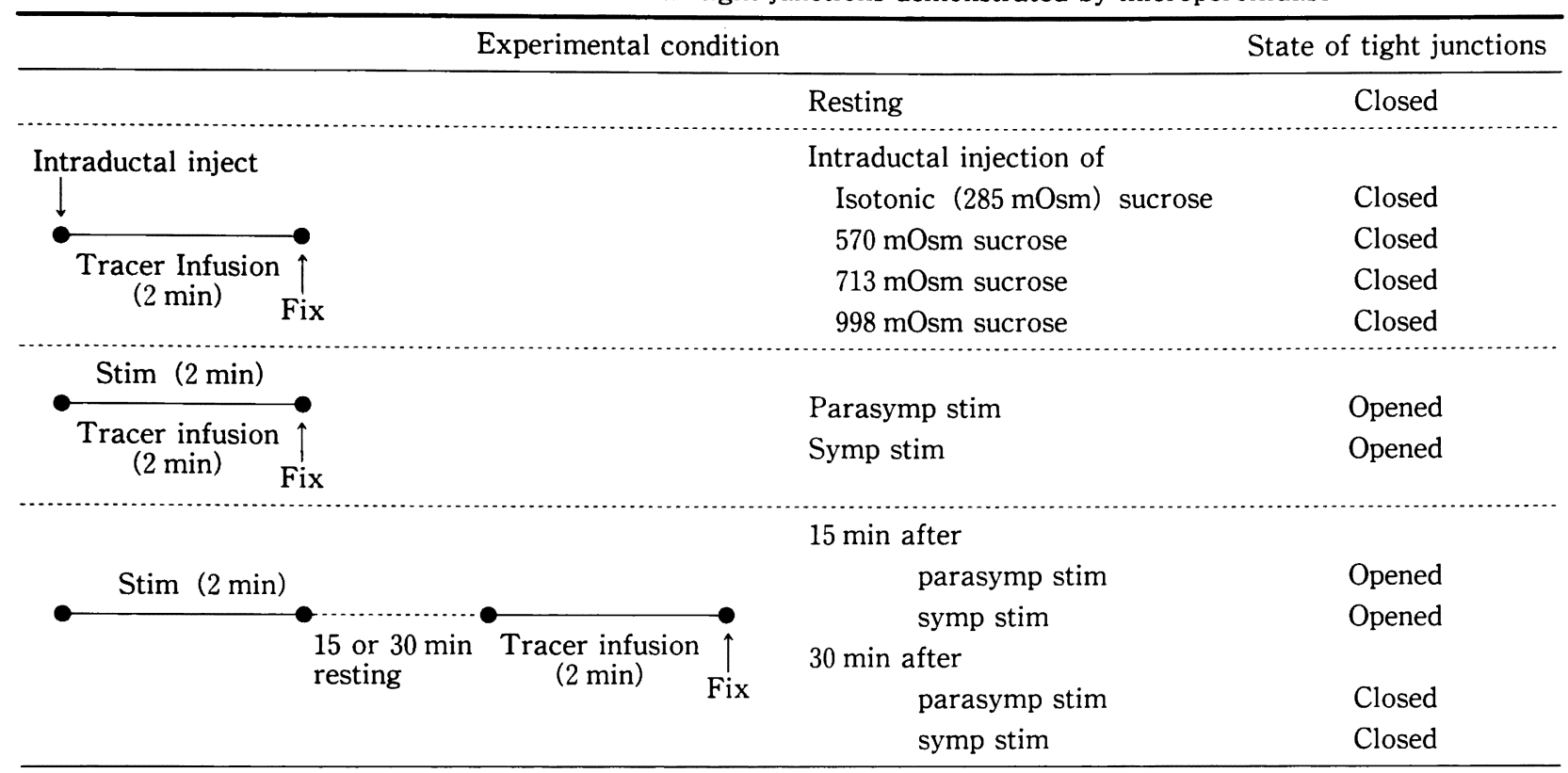

Parasymp stim : Electrical stimulation of chorda for $2 \mathrm{~min}$.

Symp stim : Electrical stimulation of superior cervical ganglion for $2 \mathrm{~min}$.

ed (Fig. 4-D). These findings indicated that tight junctions are permeable to the tracer, and thus caused them to open under parasympathetic or sympathetic secretory stimulation. The tight junctions remained open 15 min later (Fig. 4-E). After stimulation of the superior cervical ganglion, the tight junctions also remained open (Fig. 4-F), and 30 min later, they had closed. The states of the acinar tight junctions using the tracer are summarized in Table 1.

\section{Discussion}

The present study revealed that secretory stimulation caused the opening of acinar tight junctions in the submandibular gland, and that the opened tight junctions did not immediately close again after the stimulation stopped.

The barrier function of the closed tight junctions of the salivary acini in the resting gland prevents the movement of salivary components into the interstitial fluid and, conversely, movement of interstitial components into the luminal saliva. There is considerable histological evidence describing the impermeability in the tight junctions of the salivary gland to extracel- lular markers such as lead ions ${ }^{18)}$ and horseradish peroxidase ${ }^{5-7)}$. Our histochemical results using microperoxidase confirmed that the resting acinar tight junction is impermeable to the tracer. In the resting gland injected intraductally with hypertonic sucrose, a sustained elevation of luminal pressure was observed. The luminal membrane of the acinar cells would be exposed by hypertonic sucrose, However, in this gland, the tight junctions remained closed. Thus, luminal pressure elevation was caused by transcellular osmotic water flowing into the lumen, due to the presence of a hypertonic solution without tight junctions open. These findings showed that acinar tight junctions are closed in the resting gland.

Stimulation of different autonomic divisions in the rat submandibular gland produces markedly different responses. Parasympathetic stimulation causes continuous and marked secretion with a relatively low concentration of protein. On the other hand, sympathetic stimulation causes only small transient secretion with a high concentration of protein. In either case, stimulation mobilizes the fluid in the acinus, and results in secretion of water by osmosis across the acini $^{1,2)}$. A confocal laser microscopic study demon- 
strated that both Lucifer Yellow and dextrans entered the lumen through acinar tight junctions after carbachol stimulation ${ }^{19}$. In addition, our previous transmission electron microscopic study using microperoxidase showed that electrical stimulation of the chorda caused an increase in the permeability of the tight junctions to the tracer ${ }^{20}$. In the present study, we showed that electrical stimulation of the superior cervical ganglion also caused an increase in the tight junction permeability to microperoxidase. Thus, these findings clearly show that submandibular acinar tight junctions switch rapidly to an opened state by the stimulation of parasympathetic or sympathetic nerves, and that primary salivary fluid is drawn into the lumen through the paracellular pathway.

We also found that the opened tight junction, as a result of the parasympathetic or sympathetic stimulation, remained open even after secretory stimulation was stopped, and the tight junction finally closed 15-30 min later. The frequency of electrical stimulation may affect the duration of opening of tight junctions. Electrical stimulation of the chorda at low frequency induces the release of acetylcholine alone from the nerve terminals, while one or more peptides, for example, substance $P$, in addition to acetylcholine, are released in response to high-frequency stimulation $^{5,21}$. It is reported that substance $P$ has an effect of opening of the tight junction ${ }^{5}$. Additionally, the extension of the stimulation period may extend the period of the opening of the tight junctions after the stimulation is stopped. When the tight junctions of an unstimulated gland were in the opened state after the stimulation had been stopped, no salivary secretion occurred because there was no driving force. The tracer entered the lumen by simple diffusion through the opened tight junction. The rapid fall of luminal pressure after nerve stimulation can be explained by water efflux from the lumen to the interstitium through the opened tight junction.

The cellular mechanisms involved in parasympathetic and sympathetic regulation in the opened and closed states of the tight junctions in rat submandibular gland are unknown. However, several possible explanations can be considered. It is well known that stimulation in rat submandibular acinar cells is a multi-stage process including signal transduction by cyclic AMP, phospholipase $\mathrm{C}_{1} \mathrm{IP}_{3}$, protein kinase $\mathrm{C}$, or activation of the $\mathrm{Ca}^{2+}$ signaling system ${ }^{22}$. For example, $\mathrm{Ca}^{2+}$ and cyclic AMP interaction with cytoskeletal elements may be involved in the opened and closed states of tight junctions ${ }^{23}$. Cyclic AMP increases paracellular permeability in the proximal tubules of the rabbit kidney ${ }^{24)}$, and removal of $\mathrm{Ca}^{2+}$ causes disorganization of tight junction elements in various epithelial tissues, including exocrine glands ${ }^{25}$. Presumably, any or all of these processes could affect junctional permeability, as observed in several other types of epithelial tissue ${ }^{3,4}$. It was also reported that shrinkage during secretion occurs as a result of cholinergic stimulation of isolated acinar cells in the rat $^{26}$. This shrinkage has also been observed in vivo in the rat submandibular gland perfused with acetylcholine ${ }^{27)}$. It is possible that acinar cell shrinkage results in some form of mechanical disruption of the tight junction, and may result in its opening.

The paracellular secretory pathway for primary salivary fluid is unlikely the only secretory pathway, because we showed that transcellular osmotic fluid could flow into the lumen due to the luminal presence of hyperosmolarity without the tight junction being open. Judging from this observation and the results from nerve-stimulated glands, it is suggested that both the transcellular and paracellular secretory routes for the luminal fluid are present in the rat submandibular acini. The present study, however, was unable to identify the magnitude for each secretory route. A water channel protein, aquaporin 5 , has recently been identified in salivary and lacrimal glands ${ }^{28)}$ and the luminal membrane of acinar cells ${ }^{29)}$. This water channel protein may contribute to water secretion in the transcellular water transport system in the salivary acini. However, it remains uncertain whether the fluid primarily flows through the transcellular pathway across the basolateral and luminal membranes, or through the paracellular pathway through the tight junction between the acinar cells. To address this question, further investigation is necessary. 


\section{Acknowledgement}

This study was supported by the Proposal-Based New Industry Creative Type Technology R\&D Promotion Program from the New Energy and Industrial Technology Development Organization (NEDO) of Japan. We would like to express our gratitude to Drs. $\mathrm{K}$. Uchihashi and K. Higuchi for their technical help. We also thank Ms. S. Yamaoka for her editorial work and typing the manuscript.

\section{References}

1) Nauntofte, B.: Regulation of electrolyte and fluid secretion in salivary acinar cells. Am. J. Physiol. 263 : G 823-G 837, 1992.

2) Poulsen, J. H. : Secretion of electrolytes and water by salivary glands. In: Glandular mechanisms of salivary secretion. (edited by Garrett, J. R., Ekström, J. and Anderson, L. C.), pp. 55-72, Karger, Basel, 1998.

3) Schneeberger, E. E. and Lynch, R. D. : Structure, function, and regulation of cellular tight junctions. Am. J. Physiol. 262 : L 647-L 661, 1992.

4) Anderson, J.M. and Van Itallie, C. M. : Tight junctions and the molecular basis for regulation of paracellular permeability. Am. J. Physiol. 269: G 467-G 475, 1995.

5) Takai, N., Uchihashi, K., Yoshida, Y. and Kakudo, Y. : Permeability increase in rat submandibular gland by glandular substance P. Proc. Finn. Dent. Soc. 85: 339-344, 1989.

6) Garrett, J. R., Klinger, A. H. and Parsons, P. A. : Permeability of submandibular salivary glands in dogs to blood-borne horseradish peroxidase (HRP) I. Pararterial bolus injection in "resting" glands. Cell Tissue Res. 215 : 281-288, 1981.

7) Garrett, J. R., Klinger, A. H. and Parsons, P. A. : Permeability of canine submandibular glands to blood-borne horseradish peroxidase during parasympathetic secretion. Q. J. Exp. Physiol. 67 : 31-39, 1982.

8) Mazariegos, M. R. and Hand, A. R. : Horseradish peroxidase : Factors affecting its distribution after retrograde infusion into the rat parotid gland. J. Histochem. Cytochem. 33 : 942-950, 1985.

9) Wissig, S. L. and Williams, M. C. : Permeability of muscle capillaries to microperoxidase. J. Cell Biol. 76 : 341-349, 1978.

10) Van Deurs, B. and Amtorp, O. : Blood-brain barrier in rats to the hemepeptide microperoxidase. Neuroscience. $3: 737-748,1978$.

11) Feder, N. : Microperoxidase. An ultrastructural tracer of low molecular weight. J. Cell Biol. 51 : 339-343, 1971.

12) Case, R. M., Cook, D. I., Hunter, M., Steward, M. C. and Young, J.A.: Transepithelial transport of nonelectrolytes in the rabbit mandibular salivary gland. J. Membr. Biol. 84 : 239-248, 1985.

13) Howorth, A. J., Case, R. M. and Steward, M. C. : Effects of acetylcholine and forskolin on the nonelectrolyte permeability of the perfused rabbit mandibular gland. Pflügers Arch. 408:209-214, 1987.

14) Yoshida, Y., Takai, N., Uchihashi, K. and Kakudo, Y. : Sialographic damage in rat submandibular gland. Oral Surg. Oral Med. Oral Pathol. 59 : 426-430, 1985.

15) Uchihashi, K. Takai, N., Yoshida, Y. and Kakudo, Y. : Actual pathway of intraductally injected substances in the rat submandibular gland. Jpn. J. Oral Biol. 24 : 1043-1048, 1982.

16) Takai, N., Yoshida, Y. and Kakudo, Y. : Secretion and re-absorption of glucose in rat submandibular and sublingual saliva. J. Dent. Res. $62: 1022-1025$, 1983.

17) Simionescu, N., Simionescu, M. and Palade, G. E. : Permeability of muscle capillaries to small hemepeptides. Evidence for the existence of patent transendotherial channels. J. Cell Biol. 64:586-607, 1975.

18) Simson, J. A. V. and Bank, H. L. : Freeze-fracture and lead ion tracer evidence for a paracellular fluid secretory pathway in rat parotid glands. Anat. Rec. 208: 69-80, 1984.

19) Segawa, A., Terakawa, S., Yamashina, S. and Hopkins, C. R. : Exocytosis in living salivary glands: Direct visualization by video-enhanced microscopy and confocal laser microscopy. Eur. J. Cell Biol. 54 : 322-330, 1991.

20) Takai, N., Uchihashi, K., Miyao, H., Murakami, H. and Yoshida, Y. : Chorda-evoked opening of tight junctions in rat submandibular salivary acini demonstrated by microperoxidase. Arch. Oral Biol. 40: 1077-1080, 1995.

21) Ekström, J. : Neuropeptides and secretion. J. Dent. 
Res. 66 : 524-530, 1987.

22) Quissell, D. O. : Stimulus-exocytosis coupling mechanism in salivary gland cells. In Biology of the salivary Glands (edited by Dobrosielski-Vergoma, K.) pp 181-200. CRC Press, Boca Raton, 1993.

23) Madara, J. L., Barenberg, D. and Carlson, S. : Effects of cytochalasin D on occluding junctions of intestinal absorptive cells: Further evidence that the cytoskeleton may influence paracellular permeability and junctional charge selectivity. J. Cell Biol. $102: 2125-2136,1986$.

24) Jacobson, H. R. : Altered permeability in the proximal tubule response to cyclic AMP. Am. J. Physiol. 236 : F 71-F 79, 1979.

25) Meldolesi, J., Castiglioni, G. and Parma, R., Nassivera, N. and De Camilli, P. : $\mathrm{Ca}^{2+- \text { dependent }}$ disassembly and reassembly of occluding junctions in guinea pig pancreatic acinar cells. Effect of drugs. J. Cell Biol. $79:$ 156-172, 1978.

26) Dissing, S., Hansen, H. J., Unden, M. and Nauntofte, B. : Inhibitory effects of amitriptyline on the stimulation-induced $\mathrm{Ca}^{2+}$ increase in parotid acini. Eur. J. Pharmacol. 177 : 43-54, 1990.

27) Nakahari, T. and Imai, Y.: Transient swelling of salivary acinus induced by acetylcholine stimulation: Water secretion pathway in rat submandibular gland. J. Membr. Biol. 161 : 287-296, 1998.

28) Raina, S., Preston G. M., Guggino, W. B. and Agre, P. : Molecular cloning and characterization of an aquaporin cDNA from salivary, lacrimal, and respiratory tissues. J. Biol. Chem. 270 : 1908-1912, 1995.

29) He, X., Tse, C. M., Donowitz, M., Alper, S. L., Gabriel, S. E. and Baum, B. J. : Polarized distribution of key membrane transport proteins in the rat submandibular gland. Pflügers Arch. 433 : 260-268, 1997. 